\title{
Growth Performance and Profitability of Broilers Chickens with Vermi meal Supplementation under Total Confinement Management
}

\author{
Marcos Erram Bollido \\ (Received May 2020/Accepted November 2020)
}

\begin{abstract}
This study was conducted to determine the growth performance and profitability of broilers chicken with vermi meal supplementation under a total confinement management system. A total of 60 broiler chickens were randomly distributed to four dietary treatments: $T 1=$ commercial feed (CF), T2= CF $+2 \%$ vermi meal (VM), T3= CF $+3 \%$ VM, T4= $\mathrm{CF}+5 \% \mathrm{VM}$ inclusion in a completely randomized design. Feed conversion ratio was not significantly influenced by VM supplementation. However, the highest feed intake was recorded in broilers fed CF supplemented with $2 \%$ VM (T2) while control broilers fed only CF (T1) had the lowest feed consumption. Broiler chickens fed CF supplemented with $2 \%$ VM (T2) were recorded with the highest values of final body weight and weight gain compared to T1 group and T4 group, respectively. However, broiler in T2 group had similar values of body weights and weight gains compared to T3. Consequently, $2 \%$ level of VM had an optimum result in final weight, weight gain, and feed consumption, while comparable to the other treatments in water consumption, feed conversion ratio, dressing percentage, and carcass weight. Cost and return analysis of the dietary treatments with VM showed a negative effect, since the higher concentration of VM supplementation had the higher cost in production, due to the expensive price of imported vermin or earthworm meal.
\end{abstract}

Keywords: broiler chickens, performance, total confinement, vermi meal

\section{INTRODUCTION}

Broiler (Gallus domesticus) production plays a major role in the economic sector in most of the country's economy, including the Philippines. People depend on poultry production as the source of food and livelihood. Broiler chicken inventory is the highest in Central Luzon at 658.91 thousand metric tons of birds or 35.88 percent of the total broiler chicken inventory (PSA 2020).

One of the greatest challenges confronting the poultry industry is that broiler requires more input in particular feed. Feed is the most expensive input in poultry production (Tirosele \& Moreki 2012). Sultan (2010) indicates that poultry diet has been put at 60$80 \%$ of total cost in production and high-quality feed to remain competitive. Farmers fed their animals with available feeds that have limited amount of amino acids. However, around the world has been driven a force to find some alternative feeds with high contents of amino acids that can be used as a substitute feed to lessen the cost in feeding.

This statement supports the use of nonconventional animal protein sources like vermi as an organic feed supplement for chickens (Ncobela \& Chimonyo 2015). Research of Mahamba (2018) shows that the supplementary feeding of vermi or earthworms has a potential to increase egg production in village chicken and the diet with 12\% CP (earthworm + maize meal) shows the best results for experiment compared

Agriculture and Other Related Programs, Northwest Samar State University, Rueda St., Brgy Balud, Calbayog City, Samar 6710

Corespondenc Author: Email: markbollido@yahoo.com to the other diets used. Study conducted by Köse \& Öztürk (2017) shows that earthworms have nutrient contents that are close to those of the fish meal and more valuable than those of soybean meal; and for this reason, they may be used as a potential alternative for fish meal and soybean meal. Moreover, it has been reported that the protein content of vermi meal is close to that of Peru fishmeal and higher than that of Chinese fish meal, hen egg, and soybean meal including essential amino acids, especially lysine which is not found in the other feed stuffs, and it has been found that vermi meal contains a large amount of proteins and essential amino acids (Dedeke et al. 2013).

According to Kasye (2016), the results of proximate analysis showed that vermi or earthworm meal contained $66.88 \%$ of crude protein, $7.68 \%$ of crude fiber, $11.39 \%$ of ash, $9.31 \%$ of ether extract, and $17.38 \%$ of moisture. Therefore, it can be concluded that vermi or earthworm meal can be used to replace the basal diet of poultry feed as a source of protein. Moreover, vermi meal can be used as a substitute for fish meal and soya bean meal, due to their high protein content which ranges around 64-76\% (Prayogi 2011).

The vermi or earthworm has high quality protein content along with antimicrobial and antioxidant compounds that can be used as a feed supplement in broiler diet. Moreover, it has been reported that it has no anti-nutrient factor which decline the performances of broilers. Bahadori et al. (2017) emphasize that vermi or earthworm meal is superior compare to fish meal in term of protein content.

In the study of Lourdumary \& Uma (2013), earthworm powder meal was reported to contain large amounts of protein $(31.7 \%)$, iron $(241.1 \mathrm{ppm})$, soluble nitrogen (1.8\%), zinc (32.34 ppm), manganese (17.2 
ppm), and copper (4.501 ppm). Rezaeipour et al. (2014) show that earthworm powder has notable quantities of potassium, calcium, magnesium, phosphorus, and carbohydrate. These nutrient contents indicate that this type of earthworm contains potentially useful quantities of many nutrients that are important for animal and human health. It has been found that growth performance of broilers fed diets containing vermi meal is equal to that fed with fishmeal. Therefore, it can be concluded that vermi or earthworm meal can be used to replace basal diet of poultry feed as a source of protein ((Mengist 2016).

Zhu et al. (2010) reported that the average feed consumption and the feed conversion rate of birds fed earthworm powder decreased compared with $0 \%$ fishmeal $+0 \%$ of earthworm powder, and there were no significant differences among all the test groups. The $3 \%$ fishmeal $+2 \%$ earthworm powder had the highest daily weight gain at all stages. By the later period of growth, there was no significant difference between the fishmeal and the control group. However, the treatments with $3 \%$ fishmeal $+2 \%$ earthworm powder and $0 \%$ fishmeal $+5 \%$ earthworm powder had significant differences on daily weight gain from the control group, with the increases in weight gains were 10.57 and $8.77 \%$, respectively.

The improvement of body weight of broilers fed with earthworm meal may be attributed to the antibacterial characteristics of vermi meal (Julendra et al. 2012). Vermi meal is featured by its high protein content that ranges between $58 \%$ and $71 \%$ dry weight (Tiroesele \& Moreki 2012). Due to the high protein contents that ranges from 60 to $70 \%$ in vermi meal, supplementation of chicken ration with vermi meal results in the increasing weight gain of broilers with specifically high breast muscle (Bahadori et al. 2015). The effectiveness of $3 \%$ level of verme or earthworm supplementation in producing acceptable carcass and bone in broilers, the gizzard weight reduced with the inclusion of earthworm meal and no dietary effect was seen in gizzard $\mathrm{pH}$. The highest intestine weight was observed in birds supplemented with $3 \%$ of vermi while the least was observed in birds supplemented with $10 \%$ of vermi meal. The bone strength increased as the inclusion level of vermi meal increased, but was less than control without vermi meal supplementation. Nevertheless, ash content decreased with the increased inclusion level of earthworm meal in the diet (Gunya et al. 2019). Vermi meal contains essential amino acids, especially lysine which is limiting in many foodstuff. Vermi meal also has lubricant, which contains antimicrobial activity. Therefore, antibiotic characteristics of worm meal could stimulate the thinning of the intestinal mucosa and increase the nutrients absorption and feed efficiency (Olawumi \& Fagbuaro 2011). Vermi or earthworm increase protein on gizzards which make them gain weight. The feed that is rich in protein causes a definitely higher acidity in the gizzard than the feed lower in protein (Prayogi 2011). Feeds rich in protein cause the secretion of a larger quantity of stomach juice. Probably this condition is compensated by the promotion of digestion through strong movements of the gizzard. The gastric juice secreted from the proventriculus has to have a $\mathrm{pH}$ around 2 (Khajavi et al. 2015).

Vermi meal is a potential ingredient and a good source of protein for poultry diet that can be used to improve growth performance. Hence, this study was conducted to determine the effect of varying levels of vermi meal as feed supplement on the growth performance of broiler and profitability.

\section{Objectives}

Generally, this study aims to determine the potential of earthworm meal as a supplement for chickens and its effects on their growth performances and profitability. The specific objectives of the study were as follow: First, to determine the effect of vermi meal supplementation on the growth performance of broiler in terms of; a) Body Weights (average initial weight, average final weight, and average weight gain), b) Feed Consumption, c) Feed Conversion Ratio, d) Water Consumption, and e) Dressing percentage. Second, To calculate the production and profitability of broiler as were affected by varying levels of vermi meal in terms of: a) Production cost, b) Profit, and c) Return of investment.

\section{MATERIALS AND METHOD}

\section{Experimental Design and Treatments}

A total of 60 birds were used in this study covering a period of 5 weeks or 35 days. The experimental birds were randomly distributed to four treatments replicated three times with five birds per treatment taken as sample. A completely randomized design (CRD) was used in this study.

\section{The treatments used were as follow:}

$\mathrm{T}_{1}$ - Control (100\% commercial feeds)

$\mathrm{T}_{2}-98 \%$ Commercial feeds $+2 \%$ Vermi meal

$\mathrm{T}_{3}-97 \%$ Commercial feeds $+3 \%$ Vermi meal

$\mathrm{T}_{4}-95 \%$ Commercial feeds $+5 \%$ Vermi meal

\section{Vermi meal Preparation}

Vermi meal was purchased according to the computed amount needed for the study. Vermi meal was the product of the dried or milled vermin (Figure 1). Soil that are rich in vermi were screened to separate the vermi from the soil. The vermi collected were dried by laying them out in the sun or by using an artificially drying system. The amount of soil contamination is directly correlated to the meal's ash content.

\section{Feeding Management}

Experimental broilers were subjected to restricted feeding management (Figure 2). Feed and water were given according to the required amount needed by the broilers during the whole duration of the study. Fifty 


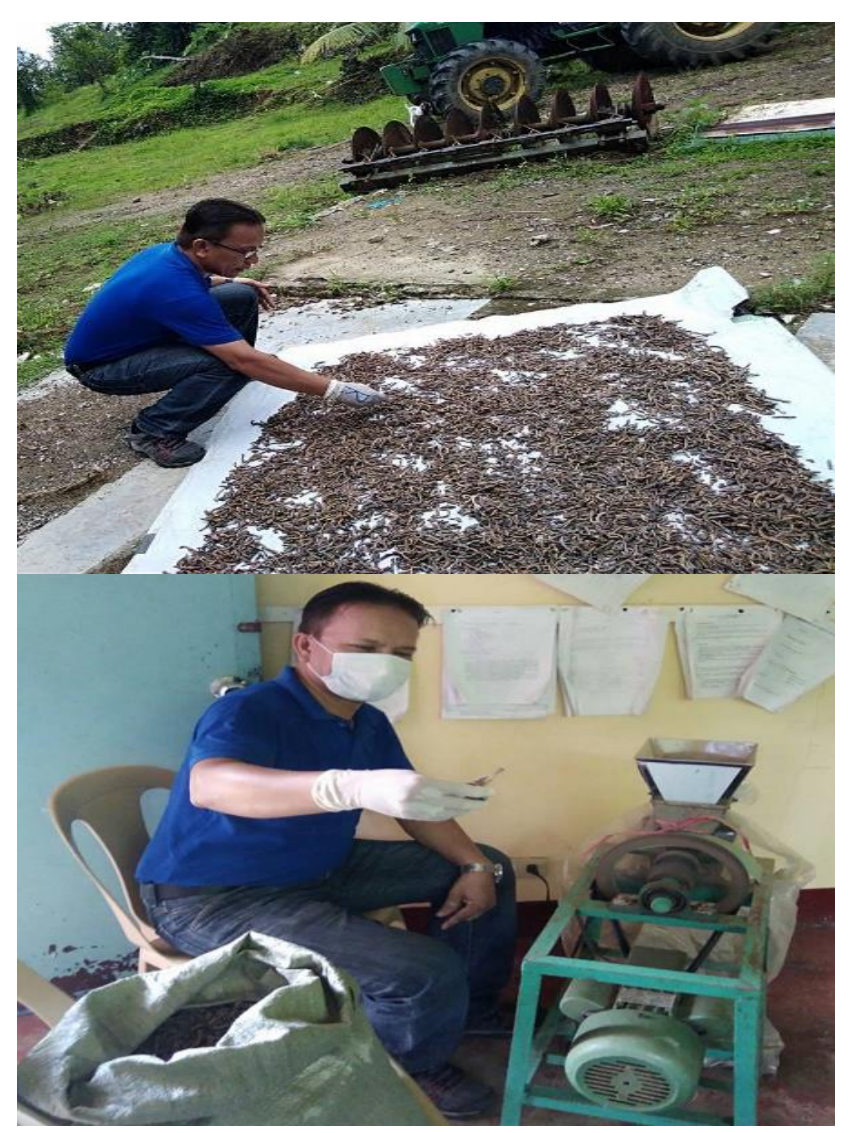

Figure 1 Drying and grinding of dried vermi.

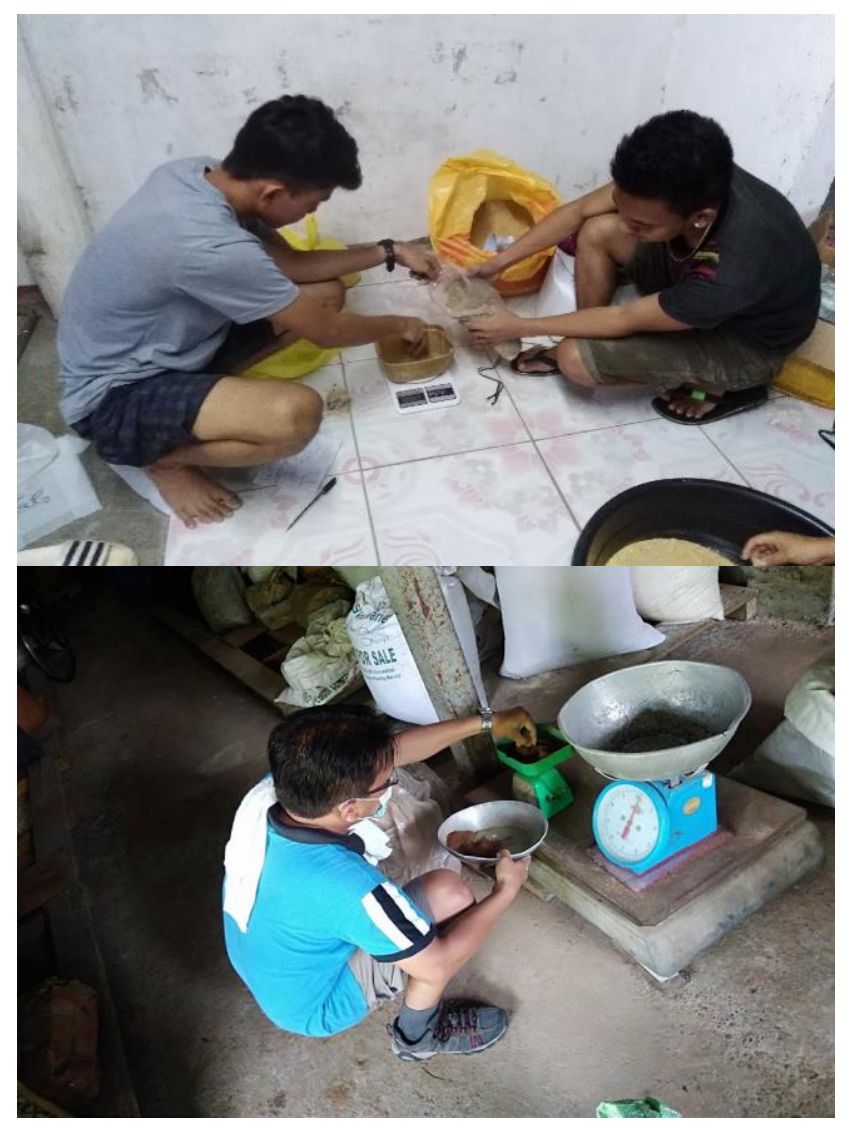

Figure 2 Measuring of commercial feeds and vermi meal.
(50) grams per head a day of chick booster mash (CBM) was given to the broilers during the brooding stage of 2 weeks, while 80 grams per head a day of broiler starter crumble (BSC) was given in the growing stage for 2 weeks, and for the finishing stage of broiler for the last 1 week they were provided with 120 grams per head a day of broiler finisher crumble (BFC).

\section{Housing and Bird Management}

The experimental birds were raised in disinfected poultry house cages (Figure 3). The floor and wall of the poultry house were constructed using bamboo slats. Feeding, watering troughs, and brooding equipment were provided in each experimental treatment and its replicate to avoid contamination of feeds among the treatment. A 5-watt bulb in every brooding cage was installed for heating within 24 hours or by the time the broiler chicks arrived until four week of brooding and was adjusted by observing the behavior of chicks.

\section{Data Analysis}

Data in each parameter were subjected to ANOVA (Analysis of Variance) using software STAR (Statistical Tool for Agricultural Research) and significant differences among treatment were determined using LSD (Least Significance Difference) test.

\section{RESULTS AND DISCUSSION}

\section{Average Weight Gain, Final Weight, and Feed Conversion Ratio}

The average weight gain of birds (Table 1) was best showed by $\mathrm{T}_{2}(2 \%)$ followed by $\mathrm{T}_{3}(3 \%)$, then $\mathrm{T}_{1}(0 \%)$ and $\mathrm{T}_{4}(5 \%)$. Supplementation of $2 \%$ vermi meal $\left(\mathrm{T}_{2}\right)$ to the diet of broilers significantly improved the weight

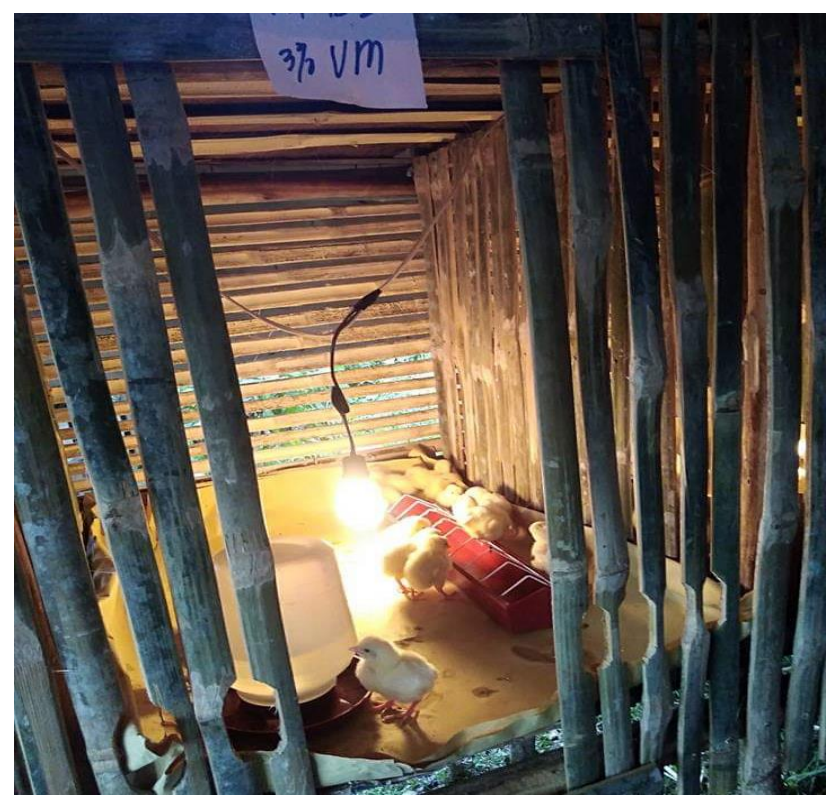

Figure 3 Brooding of day old broiler chicks. 
gain compared to those broilers given control feeds. Broilers given commercial feeds with $5 \%$ vermi meal $\left(\mathrm{T}_{4}\right)$ and pure commercial feed $\left(\mathrm{T}_{1}\right)$ showed the lowest result than all of the other treatments. Analysis of data also showed the same result on the final weight which were significantly higher in birds supplemented with $2 \%$ vermi meal $\left(\mathrm{T}_{2}\right)$. The result for this variable, $\mathrm{T}_{3}(3 \%)$ had the better feed conversion ratio with a mean of 1.69 followed by $\mathrm{T}_{2}(2 \%)$ with 1.78 , then $\mathrm{T}_{1}(0 \%)$ with 1.82 , and $\mathrm{T}_{4}(5 \%)$ got the least feed conversion ratio of 1.88 . However, statistical analysis showed no significance difference among the treatments.

\section{Feeds and Water Consumption}

The feed consumption (Table 2) was significantly influenced by the varying level of vermi meal given to the broiler. Among the four treatments, control or the broilers given $100 \%$ commercial feeds rated the lowest average feed consumption. In the study, treatments with $3 \%$ vermi meal (T3) and 5\% vermi meal (T4) had no significance difference implying that the amounts of vermi meal on the commercial feed in both treatments have a similar effect on the feed consumption of experimental broiler. The higher feeds consumed was shown and observed in T2 with $2 \%$ vermi meal added to the $98 \%$ commercial feed. T2 result showed that the addition of $2 \%$ vermi meal into the diet of broiler improved the feeding habit of broilers that made the feed intake increased compared to the rest of the vermi meal treatments and control. The higher feed consumption of broiler fed low inclusion of vermi meal was related to the fact that the diet was more palatable to the experimental broilers compared to the other rations with different levels of vermi meal.

Analysis of data revealed that the water consumptions of experimental broilers were similar among the treatments. According to the study of Nalunga (2019), birds fed ration supplemented with $3 \%$ vermi or earthworm meal had the highest body weight gain, followed by birds fed ration supplemented with $5 \%$ vermi or earthworm. The highest feed consumption was found in control broiler without vermi meal supplementation and experimental broilers fed ration supplemented with $1 \%$ of vermi meal with the lowest feed consumption was found in broiler fed ration supplemented with $7 \%$ vermi meal for all weeks of observation. There was a significant difference in the feed consumptions for week 4 and week 6 .

\section{Average Dressing Percentage and Carcass Weight}

The averages dressing percentage and average carcass weight (Table 3 \& Figure 4) of experimental broilers were not significantly influenced by the dietary supplementation of vermi meal. However, there is a numerically small difference when it comes to the mean between the treatments. It showed that experimental broilers fed ration supplemented with vermi meal or earthworm meal at the level of $3 \%\left(\mathrm{~T}_{3}\right)$ had the highest dressing percentage followed by the control broiler without permi meal supplementation $\left(T_{1}\right)$ and experimental broiler fed ration supplemented with vermi meal at the level of $2 \%\left(\mathrm{~T}_{2}\right)$ then broilers fed ration supplemented with vermi meal at the level of $5 \%$ $\left(\mathrm{T}_{4}\right)$ got the least average dressing percentage.

Table 1 Average weight gain, average final weight, and feed conversion ratio of broilers in 35 days

\begin{tabular}{lccc}
\hline \multicolumn{1}{c}{ Treatment } & Average weight gain $(\mathrm{g})$ & Average final weight $(\mathrm{g})$ & $\begin{array}{c}\text { Feed Conversion } \\
\text { Ratio }(\mathrm{g})\end{array}$ \\
\hline T1- Control & $1215.30^{\mathrm{b}}$ & $1259.33^{\mathrm{b}}$ & 1.82 \\
T2- 2\% vermi meal & $1361.80^{\mathrm{a}}$ & $1391.33^{\mathrm{a}}$ & 1.78 \\
T3- 3\% vermi meal & $1289.87^{\mathrm{ab}}$ & $1318.00^{\mathrm{ab}}$ & 1.69 \\
T4- 5\% vermi meal & $1197.20^{\mathrm{b}}$ & $1239.33^{\mathrm{b}}$ & 1.88 \\
\hline CV $(\%)$ & 5.10 & 4.46 & 4.73 \\
\hline
\end{tabular}

Description: Column with common letters were not significantly different, based on LSD test at $p<0.05$.

Table 2 Feed consumption and water consumption of broilers in 35 days

\begin{tabular}{lcc}
\hline \multicolumn{1}{c}{ Treatment } & Average feed consumption $(\mathrm{g})$ & Average water consumption $(\mathrm{mL})$ \\
\hline T1- Control & $2206.73^{\mathrm{c}}$ & $5435.67^{\mathrm{a}}$ \\
T2- 2\% vermi meal & $2301.73^{\mathrm{a}}$ & $5320.00^{\mathrm{a}}$ \\
T3- 3\% vermi meal & $2251.73^{\mathrm{b}}$ & $5657.33^{\mathrm{a}}$ \\
T4- 5\% vermi meal & $2253.87^{\mathrm{b}}$ & $5816.33^{\mathrm{a}}$ \\
CV (\%) & 1.01 & 5.46 \\
\hline
\end{tabular}

Description: Column with or without common letters were not significantly different, based on LSD Test at $p<0.05$.

Table 3 Average dressing percentage and carcass weight of broiler in 35 days

\begin{tabular}{lcc}
\hline \multicolumn{1}{c}{ Treatment } & Average dressing percentage (\%) & Average carcass weight $(\mathrm{kg})$ \\
\hline T1- Control & $78.52^{\mathrm{a}}$ & $1.18^{\mathrm{a}}$ \\
T2- 2\% vermi meal & $78.12^{\mathrm{a}}$ & $1.16^{\mathrm{a}}$ \\
T3- 3\% vermi meal & $83.02^{\mathrm{a}}$ & $1.15^{\mathrm{a}}$ \\
T4- 5\% vermi meal & $79.47^{\mathrm{a}}$ & $1.07^{\mathrm{a}}$ \\
CV $(\%)$ & 6.22 & 0.0555 \\
\hline
\end{tabular}

Description: Column without letter were not significantly different, based on LSD Test at $p<0.05$. 
However, in average carcass weight, control broiler without vermi supplementation $\left(T_{1}\right)$ rated the highest weight followed by broiler fed ration supplemented with vermi meal at the levels of 2\% $\left(T_{2}\right)$ and $3 \%\left(T_{3}\right)$ then broilers fed ration supplemented with vermi meal at the level of $5 \%\left(T_{4}\right)$ showed the lowest average carcass weight.

\section{Production, Profit, and Return of Investment}

The results of cost and return analysis of the study are presented in Table 4. This analysis showed that the control experimental broiler without vermi meal supplementation (T1) had the highest profit and return of investment while experimental broilers supplemented with vermi meal at the levels of $2 \%\left(\mathrm{~T}_{2}\right)$, $3 \%\left(\mathrm{~T}_{3}\right)$, and $5 \%\left(\mathrm{~T}_{4}\right)$ had negative results in profit and

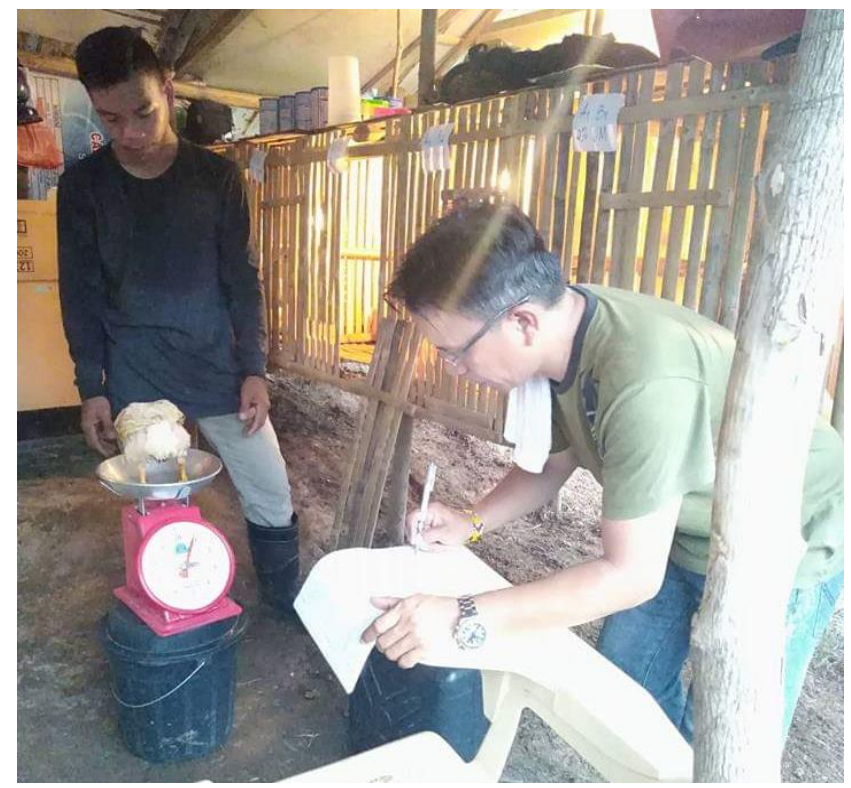

Figure 4 Weighing of broilers during harvesting. return of investment. High cost of vermi meal contributed to the negative result of the dietary treatment with vermi meal supplementation. Additional amount of vermi meal supplementation in the diets of broiler tends to increase the expenses for feed as the treatment increases.

\section{Discussion}

Average weight gain, final weight, and feed conversion ratio data showed the same results on the final weight which were significantly performed by birds supplemented with $2 \%$ vermi meal $\left(T_{2}\right)$. This result was in accordance to the study of Vu et al. (2009) that diets containing $2 \%$ vermi meal led to weight gain and increased the percentages of breast meat and leg in broiler chicken. These implied that the average weight gain and average final weight were strongly influenced by vermi meal supplementation.

The feeds consumption was significantly influenced by the varying levels of vermi meal given to the broiler. Analysis of data revealed that the water consumptions of experimental broilers had no significant difference among the treatments. However, the increased levels of vermi meal inclusion in the ration, increased the water consumption means that ranged from 200-400 $\mathrm{ml}$.

The average dressing percentage and average carcass weight of broilers showed that experimental broilers fed commercial feed supplemented with 3\% vermi meal $\left(T_{3}\right)$ had the highest dressing percentage followed by the control broiler without vermi meal supplementation $\left(T_{1}\right)$ and broilers fed ration supplemented with $2 \%$ vermi meal $\left(T_{2}\right)$ then broilers fed ration supplemented with $5 \%$ vermi meal $\left(T_{4}\right)$ got the least average dressing percentage. However, average carcass weight of control broilers without vermi supplementation $\left(T_{1}\right)$ rated the highest weight followed by the broilers fed ration supplemented with vermi meal

Table 4 Total cost, profit, and return of investment per broilers in 35 days

\begin{tabular}{|c|c|c|c|c|}
\hline \multirow{2}{*}{$\begin{array}{c}\text { Cost item (PhP) } \\
\text { Variable cost: }\end{array}$} & \multicolumn{4}{|c|}{ Treatment } \\
\hline & 1 & 2 & 3 & 4 \\
\hline Feed cost & 85.12 & 83.52 & 82.58 & 81.02 \\
\hline Vermi meal & 0.00 & 79.80 & 120.00 & 200.00 \\
\hline Broilers & 45.00 & 45.00 & 45.00 & 45.00 \\
\hline Housing disinfectant & 0.83 & 0.83 & 0.83 & 0.83 \\
\hline Bulb & 9.33 & 9.33 & 9.33 & 9.33 \\
\hline Electric bill & 8.33 & 8.33 & 8.33 & 8.33 \\
\hline Total of variable cost & 148.61 & 226.81 & 266.07 & 344.51 \\
\hline Fixed cost under depreciation: & & & & \\
\hline Digital weighing scale & 0.95 & 0.95 & 0.95 & 0.95 \\
\hline Total of fixed cost & 6.95 & 6.95 & 6.95 & 6.95 \\
\hline Total cost & 155.56 & 233.76 & 273.02 & 351.46 \\
\hline Selling price: & & & & \\
\hline Dressed chicken & 165.20 & 162.40 & 161.00 & 149.80 \\
\hline Drumstick and feet & 6.30 & 6.50 & 6.60 & 6.00 \\
\hline Internal parts: & & & & \\
\hline Heart and liver & 6.48 & 6.80 & 6.48 & 5.95 \\
\hline Gizzard & 3.85 & 3.85 & 4.20 & 3.85 \\
\hline Gross income & 181.83 & 179.55 & 178.28 & 165.60 \\
\hline PROFIT & 26.27 & -54.21 & -94.74 & -185.86 \\
\hline Return of investment & $16.89 \%$ & $-23.19 \%$ & $-34.7 \%$ & $-52.88 \%$ \\
\hline
\end{tabular}


at the level of $2 \%\left(T_{2}\right)$ and $3 \%\left(T_{3}\right)$ then $5 \%\left(T_{4}\right)$ showed the lowest average carcass weight.

Production, profit, and return of investment showed that even if the vermi meal is locally made still the result is the same. However, locally made vermi meal decreases the negative result of the return of investment and profit.

The levels of vermi meal inclusion significantly influenced the feed intake, weight gain, and final weight. The broiler fed ration with $2 \%$ inclusion level of vermi meal beneficially influenced the feed intake, weight gain, and final body weight compared to the broilers fed with pure commercial feeds without vermi meal supplementation and diets with the inclusion of much higher levels of vermi meal. Therefore, it was revealed that $2 \%$ inclusion level of vermi meal could be used as an alternative source of protein as it seems to be particularly suitable in broiler nutrition.

Vermi meal improved growth performance, carcass characteristics, and meat yield of broilers fed ration subjected to $2 \%$ and $3 \%$ vermi meal inclusion compared to those in the commercial feeds without vermi meal inclusion. Supplementation of vermi meal in the ration did not influence the FCR, water consumption, and showed a negative result in profit and return on investment because of the high cost of vermi meal. The results were consonant to the study of Zang et al. (2018) that the effects of dietary supplementation with vermi meal on production performance of broiler supplemented with $0 \%, 1 \%, 3 \%$, and $5 \%$ were the improved feed conversion ratios by $12.64-22.45 \%$. Supplementing the diet with $5 \%$ vermi meal had no negative effect on the growth of broiler and increased antioxidant enzyme.

If vermi meal were given less or without cost by means of culturing it before conducting the study then it may give much higher value of profit and return of investment because of its influenced to the weight gain and final weight of broilers. Broilers supplemented with vermi meal at $2 \%$ level had significantly higher performance, with regards to feed intake, weight gain, and final body weight of broilers.

The $2 \%$ supplementation level of vermi meal could be used as a supplementation as a protein source for broiler diets without deleterious effect on the carcass and can improve feed consumption and weight gain. For further study, modification of concentration and to validate these effects, chemical analysis and sensory of broilers should be conducted. Lastly a further study that will culture vermi for the study to have a positive effect on profit and RIO.

\section{CONCLUSION}

The levels of vermi meal supplementation significantly influenced the feed intake, gain weight, and final weight. The inclusion of vermi meal in the feed of broiler could be optimally given at $2 \%$ level since it significantly increased the broiler's final weight, weight gain, and feed consumption with comparable in water consumption, feed conversion ratio, dressing percentage, and carcass weight that of commercial feeds. Moreover, $2 \%$ inclusion level of vermi meal could be used as an alternative source of animal protein as it seems to be particularly suitable in broiler nutrition, since vermi meal has its influence on weight gain and final weight of broilers. Further research on modification of a high concentration of vermi meal supplementation and chemical analysis and sensory of broilers should be conducted.

\section{REFERENCES}

Bahadori Z, Esmaielzadeh L, Karimi-Torshizi MA, Seidavi A, Olivares J, Rojas S, López S. 2017. The effect of earthworm (Eisenia foetida) meal with vermi-humus on growth performance, hematology, immunity, intestinal microbiota, carcass characteristics, and meat quality of broiler chickens. Livestock Science. 202: 74-81. https://doi.org/10. 1016/j.livsci.2017.05.010

Bahadori Z, Esmaylzadeh L, Torshizi MAK. 2015, January. The effect of earthworm (Eisenia fetida) and vermihumus meal in diet on broilers chicken efficiency and carcass components. In Biological Forum. 7(1): 998.

Dedeke GA, Owa SO, Olurin KB, Akinfe AO, Awotedu OO. 2013. Partial replacement of fish meal by earthworm meal (Libyodrilus violaceus) in diets for African catfish, Clarias gariepinus. International Journal of Fisheries and Aquaculture. 5(9): 229233.

Julendra H, Damayanti E, Lusty Istiqomah SN, Karimy MF. 2012. The effectiveness of earthworm meal supplementation as antibiotic growth promoter replacer with different processing method. The First Poultry International Seminar, pp 146-157.

Gunya B, Muchenje V, Masika PJ. 2019. The potential of Eisenia foetida as a protein source on the growth performance, digestive organs size, bone strength and carcass characteristics of broilers. Journal of Applied Poultry Research. 28(2): 374-382. https:// doi.org/10.3382/japr/pfy081

Khajavi HR, Karimi TMA, Ahmadi H. 2015. Effect of feeding different levels of dietary vermihumus on growth performance and meat quality in broiler chickens. Journal of Animal Production. 16: 49-58.

Köse B, Öztürk E. 2017. Evaluation of Worms as a Source of Protein in Poultry. Selcuk Journal of Agriculture and Food Sciences. 31(2): 107-111. https://doi.org/10.15316/SJAFS.2017.27

Lourdumary AB, Uma K. 2013. Nutritional evaluation of earthworm powder (Lampito mauritii). Journal of Applied Pharmaceutical Science. 3(3): 82. 
Mahamba TA. 2018. Effect of Earthworm (Eisenia Foetida) Protein Based Diet as a Supplement for Village Chicken Egg Production in Gutu District, Masvingo (Doctoral dissertation, BUSE).

Mengist BK. 2016. Evaluation of Earthworm (Eisenia fetida) as a Protein Supplement for Chicken Production in Haramaya University Poultry Farm. Thesis.

Nalunga A. 2019. Earthworms (Eudrilus Eugeniae) as a potential source of proteins in poultry feeds (Doctoral dissertation, Makerere University).

Ncobela CN, Chimonyo M. 2015. Potential of using non-conventional animal protein sources for sustainable intensification of scavenging village chickens: A review. Animal Feed Science and Technology. 208: 1-11. https://doi.org/10.1016/ j.anifeedsci.2015.07.005

Olawumi, S.O. and Fagbuaro, S.S., 2011. Productive performance of three commercial broiler genotypes reared in the derived savannah zone of Nigeria. International Journal of Agricultural Research. 6(11): 798-804.

[PSA] Philippines Statistics Authority. 2020. Chicken Situation Report, January-March 2020. Philippine Statistics Authority (PSA). https://psa.gov.ph/ livestock-poultry-iprs/chicken.

Prayogi HS. 2011. The effect of earthworm meal supplementation in the diet on quail's growth performance in attempt to replace the usage of fish meal. International Journal of Poultry Science. 10(10): 804-806. https://doi.org/10.3923/ ijps.2011.804.806
Rezaeipour V, Nejad OA, Miri HY. 2014. Growth performance, blood metabolites and jejunum morphology of broiler chickens fed diets containing earthworm (Eisenia foetida) meal as a source of protein. International Journal of Advanced Biological and Biomedical Research. 2(8): 24832494.

Sultan BE, Bowes EH, van der Walt JC. 2010. Influence of different housing systems on the performance of hens of four laying strains. South African journal of animal science. 25: 80-86.

Tiroesele B, Moreki JC. 2012. Termites and earthworms as potential alternative sources of protein for poultry. International Journal for Agro Veterinary and Medical Sciences (IJAVMS). 6(5): 368-376. https://doi.org/10.5455/ijavms.174

Vu Dinh T, Han Quang H, Nguyen Dinh L, Van Duy N. 2009. Use of redworms (Perionyx excavatus) to manage agricultural wastes and supply valuable feed for poultry. Livestock Research for Rural Development. 1-8.

Zang YT, Bing S, Zhang YZ, Sheng XW, Shu DQ. 2018. Effects of dietary supplementation with earthworm powder on production performance, blood characteristics, and heavy metal residues of broiler Pullets. Journal of Applied Poultry Research. 27(4): 609-615. https://doi.org/10.3382/ japr/pfy024

Zhu Y, Li W, Zhang Y, Cao M, Wang C. 2010. Effect of earthworms powder on growth performance, metabolic rate and immune functions of broilers. Journal of Shenyang Agricultural University. 41(6): 695-700. 